\title{
Transatlantic spaces: production, location and style in 1960s-1970s action-adventure TV series
}

Article

Accepted Version

Bignell, J. (2010) Transatlantic spaces: production, location and style in 1960s-1970s action-adventure TV series. Media History, 16 (1). pp. 53-65. ISSN 1469-9729 doi: https://doi.org/10.1080/13688800903395460 Available at https://centaur.reading.ac.uk/17666/

It is advisable to refer to the publisher's version if you intend to cite from the work. See Guidance on citing.

To link to this article DOI: http://dx.doi.org/10.1080/13688800903395460

Publisher: Taylor \& Francis

All outputs in CentAUR are protected by Intellectual Property Rights law, including copyright law. Copyright and IPR is retained by the creators or other copyright holders. Terms and conditions for use of this material are defined in the End User Agreement.

www.reading.ac.uk/centaur 
Central Archive at the University of Reading

Reading's research outputs online 
Transatlantic spaces: Production, location and style in 1960s-70s Action-Adventure TV Series

Jonathan Bignell

$\underline{\text { Abstract }}$

This article argues that transatlantic hybridity connects space, visual style and ideological point of view in British television action-adventure fiction of the 1960s-70s. It analyses the relationship between the physical location of TV series production at Elstree Studios, UK, the representation of place in programmes, and the international trade in television fiction between the UK and USA. The TV series made at Elstree by the ITC and ABC companies and their affiliates linked Britishness with an international modernity associated with the USA, while also promoting national specificity. To do this, they drew on film production techniques that were already common for TV series production in Hollywood. The British series made at Elstree adapted versions of US industrial organisation and television formats, and made programmes expected to be saleable to US networks, on the basis of British experiences in TV co-production with US companies and of the international cinema and TV market.

\section{$\underline{\text { Keywords }}$}

Television, import, export, studio, Americanisation, Britain 
This article analyses the relationship between the physical location of popular television series production, the aesthetics of place in the programmes made there, and the relationship of these two issues with the international trade in television fiction in the later 1960s, especially between Britain and the USA. The main example discussed here is Elstree Studios and the programmes produced using its facilities, as a case study for exploring popular British series in a key period for international programme exchanges, focusing on the links between physical space, visual style and ideological point of view that are implied by the concept of mise-en-scène. This analysis puts pressure on the notion of 'taking place', by emphasising the significance for television history of what space and place mean. Mise-en- scène has been defined in a range of ways, but the broad definition developed by John Gibbs draws attention to visual space in a way that grounds the approach of this article. In film, he argues, mise-en-scène refers to the contents of the frame and the way they are organized, thus including the settings, the framing of space and the performers' relationship with it, and aspects of visual style such as camera movement and lighting. So when a programme takes place, important aspects of its signification include how it uses the resources of the place where it was made, and how it represents space and place for the viewer on the space of the screen. Taking account of the circumstances of production and distribution of programmes should also include the specification of which geographical places and viewers the programme is addressed to. Each of these issues has the potential to contribute to the historiographic analysis of television cultures in particular times and places. The analysis of transnational television draws attention to notions of place and space, especially the distinctiveness of places and 
the distinctions between places. This article aims to show that place and space, articulated in the audio-visual discourses in television programmes that tell the viewer where the represented places are (or appear to be), render place and space in relational and somewhat unstable ways. In the context of programmes made for transnational exchange, the identifications of 'here' and 'there', or 'us' and 'them', work by establishing distinctions and comparisons, and by loading space with relational and transformable meanings.

In the context of a discussion of Elstree Studios, a possible confusion between terms requires brief clarification. While in film production the term 'studio' can identify the company that makes the film, it can also mean the site housing the production, such as Elstree Studios in the suburban town of Borehamwood near London. Each enclosed production space on such a site is a soundstage, which is distinct from the television studio as such that is designed for productions using electronic television cameras. This article concerns the production of filmed television using film cameras on soundstages, backlot sets built on the studio premises, and shooting in outside locations. The predominant production method for television fiction in Britain until the late 1950s was to shoot in a multi-camera television studio, in monochrome using electronic cameras, and to broadcast live performance, since videotape technology became available only in 1958. Brief filmed sequences were inserted into live and later into videotaped as-if-live dramas, usually in order to establish the location of the action by showing building exteriors and landscapes, or to include special effects that could not be created in the television studio. Soundstages and backlot spaces at film studio production sites were used to make cinema films, rather than television programmes. 


\section{Elstree as a production site}

Feature film production took place at Associated British Picture Corporation's site at Elstree following its opening in the 1920s. In 1952, APBC saw an opportunity to use its facilities for filmed television production when the American NBC network hired British soundstages for one of its programmes, and transatlantic co-produced filmed television production began at Elstree with Martin Kane, Private Investigator in 1957. ABPC had business links with the British ABC Television company, which held the regional weekend franchise for the Midlands and North areas of commercial ITV broadcasting. ABC used Teddington Studios in London as well as sharing studios with the franchiseholder ATV which was based in Aston in the Midlands. These facilities could only shoot on electronic studio cameras, so Elstree's soundstages were used in the late 1950s and early 1960s for filmed television financed by ABC, ABPC and other companies, including Dial 999, Tales From Dickens, The Flying Doctor, International Detective and the co-production between ATV and ABC, Sir Francis Drake. In 1958-9, the television spin-off from the film The Third Man was made partly at Elstree, co-produced by the BBC and National Telefilm Associates, with further sequences shot at Desilu Studios in Los Angeles. Gradually Elstree was monopolized by the British production companies ABC, ITC and their associated companies in the 1960s, who made programmes for British ITV broadcasters but crucially also for sale to the US networks (Chapman 9-12). Long-running detective and adventure drama formats had been imported from America (especially by ITV), in the form of Westerns such as Rawhide and Gunsmoke, crime dramas including 77 Sunset Strip and M Squad, and spy series that included The Man 
from UNCLE, I Spy and Mission Impossible. ABC and ITC sold series like The Avengers, The Saint, The Prisoner and The Champions in the similar formats of crime, espionage and costume adventure back to the USA, and also domestically to British broadcasters. The programmes were therefore hybrids for American and British distribution, and had emerged out of American programmes some of which were co-produced with British companies, or shot partly in Britain. When ABC or ITC sold their programmes in Britain and the USA, they were already hybrids of British and North American components, often featured American actors or production personnel, and were made on a studio site whose facilities and business model resembled that of American studios (Sellers). Canadians were often employed in British television in this period, because they did not need work permits. Canada is a member of the Commonwealth with strong historical connections with Britain, and Canadian citizens could be engaged at relatively short notice and without extensive paperwork. American personnel needed work permits, but had been arriving in some numbers during the 1950s because of the terrorisation of media professionals by Senator McCarthy's Senate Sub-committee on Investigations and the House Unamerican Activities Committee (Neale), and in the 1960s as a result of political resistance to the Vietnam War. So as well as there being economic motives for British producers to borrow aesthetic and generic forms from American television to increase export potential for British series, expertise and personnel from America, and Canadians with knowledge of American broadcasting were available for positions both behind and in front of the camera.

In terms of spatial representation, the use of film in soundstage interiors, local British locations, stock footage of foreign locations, back-projected exteriors blended 
with soundstage foregrounds, and specially shot film recorded abroad enabled these drama series to develop a distinctive spatial aesthetic that is a national and international hybrid. These series set up a linkage between Britishness and international modernity, classlessness and consumerism at several levels. Aesthetically, these series developed a distinctive generic style now termed telefantasy (Johnson) in which place, and movement between places and spaces were important attractions. In ABC's and ITC's action adventure series place is specific, and the recording or witnessing of places made possible by shooting on film on location enables places to be identified and marked with significance and verisimilitude. But alongside this, spatial movement between these places is a key aspect of creating a more homogenous transnational utopia comprising less differentiated places, like international hotels and airports, modern office buildings, and the urban streets and road networks of Western modernity. Economically, the use of film to mix soundstage interiors, location footage and stock shots was dependent on the availability of Elstree and other studios as production spaces (Freeman). The connections between feature film production and filmed television production that came to fruition in the 1960s in Britain link the UK and USA as television cultures within the international mediascape, and prefigure the cross-fertilisation between television and film technology that is now a routine aspect of media convergence. Narratively, the British action adventure series tend to feature international adventurers and spies who traverse, police and manage space. This instantiates a wider cultural negotiation in which the significance of Englishness (especially in The Avengers) and other kinds of spatial specificity in television representation co-exist with the notion of a global village and the comparability of spaces one with another. Politically, the filmed action-adventure series 
express the notion of a world system that needs to be stabilized and managed by elite nations and their institutional representatives, who are drawn from the UK and other major European powers, working together with protagonists hailing from the USA.

The offer of filmed action-adventure to US networks was premised on a general respect accorded to British programming because of its consonance with existing American genres, and also an assumed superiority over most US-produced series in terms of quality. As Jeffrey Miller (22) outlines, the weekly listings magazine TV Guide ran a series of editorial pieces in the 1950s and 1960s that praised the programmes spearheading the sporadic 'British invasions' of US network television. The historical series such as The Adventures of Robin Hood were understood as structured in similar ways to US Westerns, and thus like American programmes but with the additional attractions of more complex narratives than the conventional genre elements of a contest between good and evil and regular chase and fight sequences. By contrast, The Avengers used avowedly British vocabulary, costume and décor to signify its 'hip' and 'cool' milieu but with storylines that were not so different from The Man from UNCLE (Miller 64-5). In each case, different components of the series negotiated a position between conformity to the conventions of format and genre that were set in place by programmes made by US producers, and that were familiar in Britain because they had been exported there. However, the action-adventure programmes made at Elstree also aimed at product differentiation, in the sense that they were not copycat imitations of American genre productions and could therefore be perceived as distinctive. The production system of shooting on film and mixing soundstage, backlot and location footage was not one of these distinctive elements, since it was the conventional means of making Westerns, I Spy 
or Mission Impossible, for example, in Hollywood. But that production system became increasingly developed through the 1960s as Elstree itself was equipped with further facilities, adopted colour filming as the norm and expanded the parameters of actionadventure in international settings. As this production base grew, it was used to create distinctive variations on the secret agent and detective genres that were both similar to and different from their American comparators.

\section{The maximisation of spatial resources}

The economic success and audience appeal of this internationalised television mise-enscène was demonstrated by The Saint. ITC's earlier 1950s series The Adventures of Robin Hood was sold to the CBS network and was followed by The Buccaneers, The Invisible Man and Danger Man (screened by CBS as Secret Agent). The charismatic impresario Lew Grade, who ran ITC and ATV (Bignell), financed The Saint to develop the market appeal of British filmed drama in the USA. Until the early 1960s British film series were made in thirty-minute episodes, but the American market was much greater for episodes running for an hour (including commercials) and The Saint was the first important example of this format. The Saint began production at Elstree in 1962, made by Robert S. Baker and Monty Berman's production company New World for ITC/ATV. It made use of Elstree's cutting rooms, viewing theatres, prop store and construction and costume departments. A gym was built so that its star Roger Moore could train and practice action scenes between takes. A link with British film production in this period provided a key ingredient for the spatial aesthetic of The Saint's subsequent colour series, and ITC's later productions made at Elstree. The Cliff Richard musical The Young Ones was shot there in 
1961, and a quite extensive backlot town was built for the film. This exterior location within the studio complex was re-used to provide a wide range of settings for ABC's and ITC's colour series in the 1960s, including The Baron, The Saint, The Avengers, The Champions, Department $S$ and Randall And Hopkirk (Deceased). The American NBC network broadcast some black and white episodes of The Saint in New York, Los Angeles and Chicago as a test, and against expectations it drew sizeable audiences (Chapman 130). NBC wanted more episodes, but only if they were made in colour, as part of a drive to invigorate the market for colour receivers to the benefit of its parent company, the receiver manufacturer RCA. Colour was not available in the UK until BBC2's transmissions from 1967, and on ITV from 1969. The Elstree-shot colour series were at first not made primarily for ITV broadcast but for colour screening in the USA. James Chapman (10) reports that Grade expected his sale of Danger Man to CBS, The Saint to NBC and The Baron to ABC would bring in \$10 million to ITC.

Robert S. Baker set up a new production company with Roger Moore, BaMoore Productions, to shoot The Saint in colour at Elstree in 1966. In the same year, thirty episodes of The Baron had been shot in colour. Also in 1965-6, The Baron's producers Monty Berman and Dennis Spooner formed the production company Scoton to make The Champions in colour at Elstree in 1967. Scoton's work on this series persuaded Lew Grade to back two further series from them, Department $S$ and Randall And Hopkirk (Deceased), seeking further international sales. The Champions was the series that made greatest use of Elstree's backlot town and locations within the studio complex. The backlot town was dressed to represent different countries and regionally distinctive spaces in The Champions, including France and the West Indies, and alongside the 
dressing of the lot to indicate location visually, wildtrack sound and incidental music were also used to signify place. The backlot town had already been used in The Baron to represent the exteriors of foreign embassies and police stations, and as various European streets in Department $S$. The protagonist Simon Templar's apartment was located on a backlot street in The Saint episode 'The Time To Die' (1968) and the backlot also featured as the town in which the spectral Marty Hopkirk wandered at night in the Randall And Hopkirk episode 'Never Trust A Ghost' (1969).

The premise of The Champions particularly suited the production system of using backlot locations and shooting outside the studio site, in addition to soundstage sets, back projection and interiors. The three protagonists were international agents working for Nemesis, a global security organization attached to the United Nations, and thus motivated to travel the world in the same ways as ITC's other spies and adventurers. But their special powers made further spatial movement and articulation of spaces possible. In the opening episode, 'The Beginning' (1968) they crash their aircraft in Tibet after a successful infiltration of a Chinese military base. Rescued by a lost tribe, they are endowed with superhuman powers that they gradually learn to use in their work. As well as attributes such as exceptional strength and agility, they possess enhanced sight and hearing, and telepathic communication with each other. These powers, especially telepathy, transform their relationships with space by enabling them to traverse it virtually or remotely, to hear what a character in a very distant place can hear or to receive a message from a fellow agent who is hundreds of miles away. The storyline possibilities opened up by this, and the character interactions produced by interaction at a distance, motivate cross-cutting from one space to another and the narrative joining of 
different places within the same scene. The unique development of transnational action adventure produced by combining it with this fantastical premise is crucially bound up with proximity and distance, being in space and traversing space, and conduces to both rapid narrative pacing and the articulation of diverse audio-visual components together. Stylistic continuity in ABC and ITC series's settings comes in part from using the same backlot locations, and is also linked to the making of British cinema designed for international audiences, notably the Cliff Richard films made at Elstree which used its soundstages and had required the backlot to be built in the first place. The Cliff Richard film cycle of The Young Ones, Summer Holiday and Wonderful Life was deliberately international in setting and appeal, marketing both British pop culture and also the spatial mobility that was becoming an aspiration for British people in the mid-1960s as affordable air travel and package holidays began. The films also alluded to the internationalized exoticism of the James Bond cycle that began in 1962 with Doctor No (to which Wonderful Life explicitly referred in a beach scene matching the emergence of Ursula Andress from the sea in Doctor No) and contributed to the popularity of spy adventure as a format for filmed television. Cliff Richard styled himself transnationally too, borrowing his quiff hairstyle from Tony Curtis and his curled lip from Elvis Presley (Turner), matching the internationalism of youth culture in the period and the association of modernity with Americanisation. Cliff Richard's popularity in the 1960s, James Bond's narrative world and its cultural consumption, and ABC's and ITC's action adventure television made at Elstree for international sale were underpinned by similar transnational cultural currents. 
Filmed television series ensured the economic health of Elstree (and to some extent other studios such as Pinewood) because they used the soundstages for up to eighteen months, in comparison to the five or six weeks used for making a feature film. Elstree also provided offices, editing suites, a large stills, film and music library, back projection, a large water tank, an exterior cyclorama, a cafeteria and storage vaults, facilitating industrialised television production and centralization. Elstree's directors capitalized on the profitability of the site by replacing some old buildings with three new soundstages, an administration block, an underground car park, a prop store and scenery workshop and other new facilities, all of which were being completed in 1967. These buildings were used both in the industrial production of the television series, and also served as locations themselves. Sequences were set around the exteriors of the soundstages and office blocks, roads, gateways, water tanks, the underground car park and of course the backlot town. This saved money on transport costs, eliminated permissions fees for filming on private property, and saved time in setting up equipment that would otherwise have to be moved by truck and rigged in the surrounding countryside. Where places outside the studio site were used as locations, they were usually in the suburban belt around Elstree, a geographical zone now known as 'Avengerland' that consisted of light woodland, suburban streets, and some large executive homes. This deliberately English symbolic landscape was part of the appeal of the action-adventure series, counterpointing both the urban spaces of Swinging London that were also geographically close to the studio, and representations of places that were differentiated from Englishness such as locations abroad or distant British locations like 
Scottish villages. What the programmes made at Elstree did was to aesthetically and narratively link these symbolic spaces as a hybrid imagined geography.

In The Champions, for example, the opening teaser of 'Operation Deep Freeze' (1968) mixes specially shot location film with back projection made on the Elstree soundstage and then a sequence in the backlot town. The opening long shot shows a white car rounding the corner of a country road, and at the roadside the place-name St Justin can be seen on a roadsign. This footage from France then cuts to an Elstree soundstage where Richard Barrett (William Gaunt) is shown in medium shot at the wheel of the car, while behind him the camera can see further back projected film of the country road through the rear window. Getting a telepathic call to rendezvous with the other two Champions, Barrett's car is next seen driving into an Elstree backlot street where he will meet them. This suturing process of simulating spatial coherence by using footage of different kinds is an extension of the convention of inserting filmed exteriors to establish place. The gateways of the Elstree studio were dressed with some military signage, vehicles and men in uniform to become, for example, the entrances to a naval base and an army installation. Further inside the Elstree site, in 'The Search' (1969) the viewer sees naval frogmen diving into the large water tank behind the soundstages, which stands in for the dock of the naval base, and this tank also represented a dockyard in 'The Ghost Plane' (1968). Craig Stirling (Stuart Damon) dives into the same tank to escape the painful transmissions of an electronic device implanted in his ear in 'The Invisible Man' (1968), where it is now dressed to represent the port of Rotterdam in The Netherlands. Each use of these recurrent locations was embedded in the narrative of its respective episode, and details of set dressing and camera position might prevent even attentive 
viewers from noticing their repeated occurrence. But the action-adventure series were designed to offer continuity of characterization, premise, visual style and dramatic tone over long runs of episodes, and the use of the same places over and again is a visual aspect of this consistency that differentiates the television formats from individual cinema productions made at the same studio.

Despite the economic advantages of using the Elstree site in The Champions, the adaptability of space for filmed production was exploited even more after the series finished filming in early 1968. The Champions was sold to the USA for network broadcast by NBC, and also to Australia and Japan (Chapman 171), but was held back from screening in Britain until later that year, demonstrating again the significance of programme export to ITC in comparison to the servicing of British commercial channels' needs. The series' creators Spooner and Berman responded to requests from Grade to make programmes more cheaply by offering to shoot two series at the same time, sharing soundstages, props and production staff. This maximization of profitability, by using space even more industrially, was the reason for the simultaneous production of Department $S$ and Randall And Hopkirk (Deceased) during the latter half of 1968. While a few new backlot locations were specially constructed, like the graveyard set used in the opening titles and in several episodes of Randall and Hopkirk, studio buildings served as settings in both series. For example, exteriors of Elstree's office block represented an Interpol bureau and also Heathrow Airport in Department $S$, while the studio's underground car park appeared in seven episodes of Randall and Hopkirk.

Later ITC series of the1970s continued this pattern of using space, but became gradually more ambitious in the proportion of specially shot location material. The 
Persuaders!, ITC's most expensive production teaming Roger Moore with Tony Curtis as international playboy crime-fighters, used extensive specially shot sequences in European resorts. But it also made much use of the backlot town built at Pinewood studios (not at Elstree), continuing the pattern discussed here. The Protectors blended soundstage, location, library footage and back projection but with greater emphasis on the internationalization of its storylines, characters and settings. Using lightweight $16 \mathrm{~mm}$ cameras rather than ITC's customary $35 \mathrm{~mm}$ film format, the series featured the protagonists in action in Paris and Rome as well as using second unit and stock footage of these locations. The Persuaders! and The Protectors accentuated a disarticulation between social class and place that had been evident as early as The Saint, because of the later series' preponderance of foreign location shooting. ABC's and ITC's international adventurers and secret agents were often characterised as socially privileged or aristocratic, through signifiers such as the chivalric gallantry of Simon Templar or John Steed's bowler hat and umbrella in The Avengers. In The Protectors, none of the three protagonists were British, comprising Nyree Dawn Porter as the Italian Contessa di Contini, Tony Anholt as the Frenchman Paul Buchet, and American actor Robert Vaughn playing the Anglophile Harry Rule, based in London. In The Persuaders!, Lord Brett Sinclair (Roger Moore) was teamed with Danny Wilde (Tony Curtis), an American selfmade millionaire from the New York slums. The greater the movement of episode storylines between different international settings, the more easily class differences could be dislocated from their national specificity, in the Nice and Monte Carlo settings of the opening episode, 'Overture' (1971), for example. Class differences were a recurrent motif of the episodes, especially as a source of comic banter between the protagonists, 
but initially Sinclair and Moore were established as characters in storylines outside of the native British and American milieux where those differences originated. Instead, the different class identities of the characters could be portrayed as aspects of national difference, where such national differences were subsumed into an action team whose effectivity depended on their ability to move easily across borders and negotiate differences amongst themselves and with the non-recurring characters they encountered abroad. In the series' earlier episodes, the vertical stratifications of class were harmonized by the international and classless mythology of action adventure, and markers of difference were displaced onto the horizontal axis of spatial movement between the spaces where action took place. Later in The Persuaders! production, however, episodes were set more often in Britain and class and national differences were located in cultural spaces that invited Sinclair's aristocratic Englishness to become the measure of their significance.

\section{Reflexive and hybrid spaces}

The ITC series The Prisoner developed a distinctive use of space linking the significance of place in its format with an unusual location of production. The series placed an anonymous protagonist, probably a secret agent, in the architecturally hybrid space of The Village from which he tried each week to escape. Interiors were shot at Borehamwood studios in England, owned by the American MGM corporation, and comprised the contemporarily furnished domestic spaces, small shops and cafes where Village inhabitants live, along with a high-tech underground control centre reminiscent of the villains' lairs in James Bond films of the period. Exteriors were shot at Portmeirion, a 
coastal estate in Wales built by the eccentric architect Clough Williams-Ellis in the 1920s that whimsically blended buildings imported brick-by-brick from Mediterranean Europe with newly-constructed pastiches of architectural styles. One premise of the format was that the eponymous Prisoner (Patrick McGoohan), known in the Village simply as Number 6, did not know whether he was somewhere in his native England, in some kind of secret testing establishment set up by his own side, or being interrogated in an elaborate prison camp on the other side of the Iron Curtain. Studio interiors alluded both to conventional representations of familiar living spaces but also to spy cinema and fantasy adventure, while exteriors offered the spatial specificity of filmed locations but problematised the connotations of place and cultural setting by choosing to set the action in Portmeirion. Rather than simulating the identity of an existing place, as Elstree's and other studio backlots were designed to do, the Portmeirion location offered consistent exoticism and displacement from the parameters of place, befitting the simultaneous spatial enclosure and non-specificity of place required by the series' enigmatic premise.

Some episodes of the series redoubled this by referring reflexively to place as simulation. In 'The Chimes of Big Ben' (1968), the Prisoner appears to escape by loading himself into a shipping crate. He hears the sounds of dockyards, the sea and various ports, which lead him to believe that he is moving further and further from the Village. At intervals, the camera uses stock shots and back projection to suture the crate into a range of actual port and dockyard locations, following the Prisoner's journey. But at the conclusion of the episode the Prisoner finally opens the crate only to find that he is back in the London office where he used to work. The sounds of Big Ben apparently chiming in London do not match the difference in time that ought to have occurred 
during the journey, and he discovers a tape recorder from which the chimes have been played. Leaving the building he finds that he is back in The Village, and in fact he has never left it. Both the sounds and the visual sequences were simulations of place, a ruse in which the narrative's images and sounds are revealed as having been anchored only to the Prisoner's perception of them. Sound effects were played to him on tape, and the visual images were his own imagined constructions of where he surmised he was. Narratively, the journey sequence was 'really' in the Village, just as, in production terms, the whole of the 'journey' was assembled at Pinewood using studio interiors, stock shots and back projection. The episode operates both as a reflexive joke about television's production of the imaginary, at the same time as it blurs the boundaries between subjective and objective narration. Because of the ambivalence and mystery about place in The Prisoner's format and storylines, metacommentary on space and place in television became possible in the series in ways that were rarely available to other action adventure programmes.

There is very little evidence to determine whether audiences in either Britain or the USA regarded representations of place and space as important to the programmes discussed here. It is also the case that the export success of filmed series made at Elstree can be overstated, since few of them were acquired for regular US network screening and many appeared instead in syndication where regional stations could use them as inexpensive schedule-fillers. With a network slot on CBS in 1965, ratings for Secret Agent were 20 per cent higher than for the series it replaced in the schedule (Miller 41), and on $\mathrm{ABC}$ The Avengers achieved a better than average 12.3 Neilson rating and an audience share of 28.3 in 1966 (204). But these are exceptions in a larger picture where 
imported action-adventure series were given unadvantageous schedule positions and achieved poor audience figures, so they were cancelled after short runs, as the details of US transmission below make clear. Where some evidence of qualitative viewer response has been uncovered in letters to $T V$ Guide for example, it is not the spatial aesthetic of the programmes that seems to have been remarked on by American viewers. Instead, distinctive features of character or tone are important, for example in the intriguing and thrilling Secret Agent (41) or the appeal to young middle-class women of the active and assured Mrs Peel in The Avengers (68). However, these points of interest had to be mediated by production values that were acceptable to US audiences because they were comparable with domestic US television, and the lack of mention of mise-en-scène can be understood as evidence for that. The acceptance of international settings and locations was also supported by the connections between the television versions of the spy-thriller genre and iconography in other media such as the James Bond films. The trade paper Variety announced a moment of change in terms of the audio-visual quality of imported action-adventure when it declared in 1965 that Secret Agent and The Saint had 'firmly nailed a once-predominant notion that British production values are too sluggish for the US “big-league" broadcasters' (Brown). While British distinctiveness was noted by industry commentators and viewers, the opportunity to evaluate these programmes in the same ways as American ones was equally important.

The space of the screen in these late 1960s ITC series is the meeting point for a set of spatial relationships that exhibit hybridity, and throw simple fixing of identity and location into doubt. British programmes aimed for international circulation, and combined national specificity of setting with internationalism. The places seen are 
specific, but are made comparable components of a traveling culture. The British film studio, borrowing production methods refined in the USA, brought together the resources to simulate place on one physical site. Film technologies freed programmes from the enclosing television studio, making space 'real' on location, but cameras traveled between soundstage interiors, studio exteriors, artificial backlot locations, and backprojected simulations of places. The colourful and expansive modernity of action adventure television is part of a broader historical process (Osgerby, Gough-Yates and Wells) in which the power to travel in and witness real space co-exists with the simulation of spaces on a centralised production site. It is this ability to travel in virtual space by means of spectatorship, alongside special effects in cinema, tourism and theme park rides, and the marketing of consumer audio-visual technologies such as television, that Anne Friedberg has characterised as aspects of Western postmodernity. There is a continual tension in each of them between here and there, homely and exotic, real and simulated, familiar and unfamiliar, that makes place unsettling and exciting.

But although conceptions of 'here' versus 'there', or 'us' versus 'them' have shifting meanings, the patterns of interaction between here and there, or us and them, take historically specific forms. Historiographic work on spatial hybridity shows that distinction operates as a situated practice, as Mary Beth Haralovich has argued of the US series I Spy's use of foreign locations to both signify exoticism and also to offer a geography that matched Cold War perceptions of other nations and peoples. This situatedness works to ground analysis of spatiality in television, in contrast to a tendency in some critical discourses about space to evacuate specificity in favour of the homogeneity attendant on theories of globalization. While spaces and places in the 
British action-adventure series of the 1960s are often simulated, exchangeable and hybrid constructions, their significance depends on their distinctions one from another and the activity of their articulation. Articulation, here, means both the linking of places together within the narrative of a television programme and also the narrativisation of spaces that endows them with significance. Bringing dissimilar places together renders them comparable yet distinct components of a hybridly spatialised text. Similarly, at the level of television trading, the perception of Britishness and Americanness within programmes and in systems of production depends also on distinctions between a 'here' and a 'there'. By recognizing such distinctions and articulating them in emergent aesthetic forms, technological possibilities and systems of production organization, the action adventure series discussed in this article created a hybrid television form that was both British and American, and both television and film. Again, this hybridity did not dissolve the distinctions between its components, but instead questioned and shifted the boundaries between them in new ways.

\section{$\underline{\text { Acknowledgement }}$}

This article is one of the outcomes of the research project 'British TV Drama and Acquired US Programmes, 1970-2000', funded by the Arts \& Humanities Research

Council from 2005-8. The project was led by Jonathan Bignell, director of the Centre for Television Drama Studies at the University of Reading.

\section{$\underline{\text { References to television programmes }}$}

The Adventures of Robin Hood (Sapphire/ITC, UK tx. ITV 1955-9, US tx. CBS 1955-8). 
The Avengers (ABC, UK tx. ITV 1961-9, US tx. ABC 1966-9).

The Baron (ITC, UK tx. ITV 1966-7, US tx. ABC 1966).

The Buccaneers (Sapphire/ITC, UK tx. ITV 1956-7, US tx. CBS 1956-7).

The Champions (ITC, UK tx. ITV 1968-9, US tx. NBC 1968-9).

Danger Man (ITC, UK tx. ITV 1960-9, US tx. CBS (as Secret Agent) 1961).

Department $S$ (ITC, UK tx. ITV 1969-70, US tx. Syndicated 1971).

Dial 999 (Towers of London/Ziv, UK tx. 1958-9, US tx. Syndicated 1959).

The Flying Doctor (APBC, UK tx. ITV 1959-60).

Gunsmoke (Filmaster/Arness \& Co., UK tx. ITV (as Gun Law) 1956-70, US tx. CBS 1955-75).

International Detective (Official/APBC, UK tx. ITV 1959, US tx. Syndicated 1959).

The Invisible Man (Official/ITP, UK tx. ITV 1958-9, US tx. CBS 1958-60).

I Spy (NBC, UK tx. ITV 1967-9, US tx. NBC 1965-8).

The Man from UNCLE (MGM, UK tx. BBC 1965-8, US tx. NBC 1964-7).

Martin Kane, Private Investigator (Towers of London/Ziv, UK tx. ITV 1958-9, US tx.

Syndicated (as The New Adventures of Martin Kane) 1957).

Mission Impossible (Paramount, UK tx. ITV 1967-74, US tx. CBS 1966-73).

M Squad (Latimer/Universal, UK tx. ITV 1958-60, US tx. NBC 1957-60).

The Persuaders! (ITC/Tribune, UK tx. ITV 1971-2, US tx. ABC 1971-2).

The Prisoner (ITC/Everyman, UK tx. ITV 1967-8, US tx. CBS 1968).

The Protectors (ITC/Group Three, UK tx. ITV 1972-4, US tx. Syndicated 1972).

Randall And Hopkirk (Deceased) (ITC, UK tx. ITV 1969-70, US tx. Syndicated 1973)

Rawhide (CBS, UK tx. ITV 1961-6, US tx. CBS 1959-66). 
The Saint (ATV/New World/Bamore/ITC, UK tx. ITV 1962-9, US tx. NBC 1967-9).

77 Sunset Strip (Warner, UK tx. ITV 1958-64, US tx. ABC 1958-64).

Sir Francis Drake (ATV/ABC, UK tx. ITV 1961-2, US tx. NBC (as The Adventures of Sir Francis Drake) 1962).

Tales From Dickens (Towers of London, UK tx. ITV 1958, US tx (as Frederic March

Presents Tales from Dickens) 1959).

The Third Man (BBC/British Lion/National Telefilm Associates, UK tx. BBC 1959-64, US tx. Syndicated 1960).

\section{$\underline{\text { References to films }}$}

Doctor No (UA/Eon, Terence Young, 1962).

Summer Holiday (ABPC/Ivy, Peter Yates, 1963).

The Young Ones (ABPC, Sidney J. Furie, 1961).

Wonderful Life (EMI/Elstree/Ivy, Sidney J. Furie, 1964).

\section{$\underline{\text { References to printed sources }}$}

BIGNELL, JONATHAN. “And the Rest is History: Lew Grade, Creation Narratives and Television Historiography.” In CATHERINE JOHNSON and ROB TURNOCK, eds, ITV Cultures: Independent Television Over Fifty Years (Buckingham: Open University Press, 2005), 57-70.

BROWN, LES. “Britain Makes It on US TV - O'Seas Influence Makes Its Mark.” Variety, 30 June 1966, 1. 
CHAPMAN, JAMES, Saints and Avengers: British Adventure Series of the 1960s

(London: I. B. Tauris, 2002).

FREEMAN, NICK. "See Europe with ITC: Stock Footage and the Construction of Geographical Identity.” In DEBORAH CARTMELL, I.Q. HUNTER, HEIDI KAYE, and IMELDA WHELEHAN, eds, Alien Identities: Exploring Difference in Film and Fiction (London: Pluto, 1999), 49-65.

FRIEDBERG, ANNE, Window Shopping: Cinema and the Postmodern (Berkeley, CA: University of California Press, 1993).

GIBBS, JOHN, Mise-en-scène: Film Style and Interpretation (London: Wallflower, 2002).

HARALOVICH, MARY BETH. "I Spy's "Living Postcards": The Geo-politics of Civil Rights." In MARY BETH HARALOVICH and LAUREN RABINOVITZ, eds, Television, History, and American Culture: Feminist Critical Essays (Durham, NC: Duke University Press, 1999), 98-119.

JOHNSON, CATHERINE, Telefantasy (London: BFI, 2005).

MILLER, JEFFREY, Something Completely Different: British Television and American Culture (Minneapolis: University of Minnesota Press, 2000).

NEALE, STEVEN. “Transatlantic Ventures and Robin Hood.” In CATHERINE JOHNSON and ROB TURNOCK, eds, ITV Cultures: Independent Television Over Fifty Years (Buckingham: Open University Press, 2005), 73-87.

OSGERBY, BILL, ANNA GOUGH-YATES, and MARIANNE WELLS. “The Business of Action: Television History and the Development of the Action TV Series.” In BILL 
OSGERBY and ANNA GOUGH-YATES, eds, Action TV: Tough Guys, Smooth

Operators and Foxy Chicks (London: Routledge, 2001), 13-31.

SELLERS, ROBERT, Cult TV: The Golden Age of ITC (London: Plexus, 2006).

TURNER, STEVE, Cliff Richard: The Biography, $3^{\text {rd }}$ revised ed. (London: Lion Hudson, 2005). 